\title{
Response of Treated and Untreated Domestic Waste Water Irrigation on Yield, Water Productivity and Economics of Cluster Bean
}

\author{
M.V. Manjunatha*, Sunil A. Satyareddi, B.H. Prasanna Kumar and \\ Manjunatha Hebbara
}

Water for Crops Project, University of Agricultural Sciences, Dharwad-580005, Karnataka, India

*Corresponding author

\section{A B S T R A C T}

\begin{abstract}
A field experiment was conducted to study the response of Engineered constructed wetland treated and untreated domestic wastewater irrigation on vegetative growth, yield, water productivity of cluster bean and soil properties at Main Agricultural Research Station, University of Agricultural Sciences, Dharwad during Rabi/Summer 2015-16. The study consisted of six different sources of irrigation water i.e., Domestic wastewater, Engineered constructed wetland (ECWL) treated wastewater, fresh water, fresh water alternated with domestic wastewater, fresh water alternated with ECWL treated wastewater and ECWL treated wastewater alternated with domestic wastewater. Results indicated that higher yield of cluster bean $(8874 \mathrm{~kg} / \mathrm{ha})$ was recorded in domestic waste water as compared to fresh water $(5145 \mathrm{~kg} / \mathrm{ha})$. However, it was on par with treated waste water alternated with domestic waste water $(7703 \mathrm{~kg} / \mathrm{ha})$. Higher water productivity was achieved with domestic waste water $(164.03 \mathrm{~kg} / \mathrm{ha}-\mathrm{cm})$ followed by treated waste water alternated with domestic waste water $(142.38 \mathrm{~kg} / \mathrm{ha}-\mathrm{cm})$. Significantly higher net returns (Rs $1,34,440 / \mathrm{ha}$ ) and $\mathrm{B}: \mathrm{C}$ ratio (4.12) were obtained with application of domestic waste water as compared with all other treatments except treated waste water alternated with domestic waste water (Rs.1,11,023/ha and 3.58, respectively). The highest and lowest net profit of Rs 2485 and 1106 were obtained per cm use of water in case of domestic waste water and fresh water irrigation, respectively. However higher net profit of Rs 2052 per $\mathrm{cm}$ water used was also recorded in treated waste water alternated with domestic waste water. Insignificant difference with respect to soil $\mathrm{pH}$ and electrical conductivity was recorded under different sources of irrigation at $0-20 \mathrm{~cm}$ and $20-40 \mathrm{~cm}$ soil depth. Significant difference in available nitrogen content was observed at both the soil depths due to different source of the irrigation water. Higher amount of potassium was recorded in domestic waste water which was on par with treated waste water alternated with domestic waste water. Higher calcium and magnesium concentration was also recorded with domestic waste water as compared with all other sources of irrigation.
\end{abstract}

Keywords

Domestic wastewater,

Engineered

constructed wetland,

Crop performance,

Water productivity,

Economic feasibility

Article Info

Accepted:

20 June 2019

Available Online:

10 July 2019

\section{Introduction}

The re-use of wastewater in agriculture is gaining wider acceptance in many parts of the world especially in regions with water scarcity, growing urban populations, and rising demand for irrigation water (Meli et al., 2002). The discharge of untreated wastewater from households and industries is a threat to nature and humans in developing areas and causes eutrophication of surface waters and transmission of waterborne diseases, and the situation is getting worse with the rapid urbanisation without proper sanitation. About 38,354 million litres per day (MLD) sewage is generated in major cities of India, however, the total sewage treatment capacity in these cities is only 11,786 MLD (Kaur et al., 2012). 
A large portion of this surplus sewage of 26,568 MLD leads to widespread water pollution. Conventional wastewater treatment technologies such as activated sludge process, membrane bioreactors and membrane separation are rather expensive and not entirely feasible for widespread application in rural areas and they require guaranteed power supply, replaceable spare parts and a skilled labour for operation and maintenance (Chen $e t$ al., 2014; Kivaisi, 2001). Thus, selecting lowcost and efficient alternative technologies for wastewater treatment is significant especially in developing regions.

Constructed wetlands (CWs) for wastewater treatment are potentially a good solution for treating domestic and industrial wastewaters. The advantages of the CWs technology are simple to construct, operate and low operation and maintenance costs since no mechanical components or external energy supply is required (Rousseau et al., 2004; Kivaisi, 2001; Rai et al., 2013). CWs are suitable since they can be efficient in removal of BOD and pathogens whereas removal of nutrients is often more limited. Several researchers Jan Vymazal (2014), Suhad et al., (2017), Azize Dogan Demir and Ustan Sahin (2017) and Datta et al., (2016) highlighted the importance of re-use of treated waste water in water scarcity areas.

Keeping these in view the necessity of re-use of waste water for irrigation and the importance of treatment of waste water through ECWL technology, field experiments were conducted at UAS, Dharwad during rabi/summer-2015-16 to study the response of treated and untreated waste water irrigation on crop response, water productivity and economics of cluster bean.

The effect of different sources of irrigation water on soil chemical properties is also studied.

\section{Materials and Methods}

A field experiment was conducted during Rabi/Summer 2015-16 at Main Agricultural Research Station, University of Agricultural Sciences, Dharwad. The site was situated at a latitude of $15^{\circ} 26^{\prime} \mathrm{N}$ and longitude of $75^{\circ} 07^{\prime} \mathrm{E}$ with an altitude of $678 \mathrm{~m}$ above MSL and falls in the northern transitional zone of Karnataka. The soil of the experiment site was sandy clay loam with low organic carbon and soil available nitrogen and medium in available phosphorus and high in available potassium. Soil analysis of the experimental site before the conduct of the experiment is presented in table 1. Soil and water were analyzed using standard procedure indicated by Tandon (2008).

Engineered Constructed Wetland (ECWL) with capacity to treat $50 \mathrm{~m}^{3}$ day $^{-1}$ was established under Water4crops project, Department of Biotechnology, Government of India to treat the domestic wastewater generated from the University campus. ECWL treated wastewater, domestic wastewater and bore well water available at campus were used as a source of irrigation in the experiment. Macrophtyes of Typha latifolia and Bracharia mutica were used in the ECWL filled with filter bed with gravels $(<40 \mathrm{~mm})$ to a depth of $50 \mathrm{~cm}$; fine sand to a depth of $25 \mathrm{~cm}$ and charcoal to a depth of $5 \mathrm{~cm}$. The water quality parameters were analyzed at fortnightly interval and mean of the data for the growing season is presented in table 2 .

The experiment was laid out in randomized complete block design with four replications and consisted of six different sources of irrigation water i.e., T1: Domestic wastewater (DWW), T-2 : Engineered constructed wetland (ECWL) treated wastewater (TWW), T-3: Fresh water (Bore well water $-\mathrm{FW}$ ), T-4 : Freshwater alternated with domestic wastewater (FW-DWW), T-5: Freshwater 
alternated with ECWL treated wastewater (FW-TWW) and T-6: ECWL treated wastewater alternated with domestic wastewater (TWW-DWW)

Cluster bean (cv PNB) was sown on 12/01/2016 during rabi/summer 2015-16 at a spacing of $45 \mathrm{~cm} \times 20 \mathrm{~cm}$ following the recommended package of practices. Recommended dosage of fertilizer 25:75:60 $\mathrm{kg} \mathrm{N}, \mathrm{P}_{2} \mathrm{O}_{5}, \mathrm{~K}_{2} \mathrm{O} /$ ha was applied to the crop. Cumulative weight of the periodic harvest of cluster bean was accounted and presented as yield per plant. Net plot yield of cluster bean as influenced by the treatment were arrived and expressed as t/ha. Irrigation was scheduled at 50 per cent depletion of soil moisture. Volumetric method was used to measure the water applied to each plot. Two common irrigations with a depth of $30 \mathrm{~mm}$ with good quality bore well water were applied for establishment through sprinklers. Thirteen irrigations were given with an average depth of $35.2 \mathrm{~mm}$ for each irrigation and total water applied during the entire cropping period was $541.4 \mathrm{~mm}$ which includes effective rainfall of $23.4 \mathrm{~mm}$. Water productivity was calculated and expressed as $\mathrm{kg} / \mathrm{ha}-\mathrm{cm}$. Influence of the treatments on crop performance in monetary terms were expressed as net return (Rs/ha), B: C ratio and net profit per $\mathrm{cm}$ of water used. Statistical analyses of the observed biometric and yield parameters were also carried out as per Gomez and Gomez (1984). Influence of different sources of water on soil chemical properties at different depths were studied at harvest stage. Soil $\mathrm{pH}$ was determined in 1:2.5 soil-water suspension by potentiometric method using a $\mathrm{pH}$ meter. Electrical conductivity was determined using conductivity bridge. Available nitrogen in soil was estimated by following alkaline permanganate method and available potassium in soil was determined by following extraction with ammonium acetate and estimated by using flame photometer.

\section{Results and Discussion}

\section{Vegetative growth and yield parameters}

Influence of source of irrigation water on plant height was found to be significant with domestic wastewater with higher plant height $(75.15 \mathrm{~cm})$ as compared to freshwater $(63.48)$ (Table 3). More number of branches per plant was recorded under domestic wastewater irrigation (7.48) followed by treated wastewater alternated with domestic wastewater (7.38) and minimum in fresh water irrigated plots (6.35). Yield attributes includes number of fruits/plant (70.79) and fruit weight / plant $(141.57 \mathrm{~g})$ were found to be higher in domestic wastewater followed by treated wastewater alternated with domestic wastewater (67.07 and $134.15 \mathrm{~g}$, respectively).

Lesser number of fruits and fruit weight per plant were recorded in case of fresh water alone (58.37 and $119.23 \mathrm{~g})$. Higher yield $(8874 \mathrm{~kg} / \mathrm{ha})$ was recorded with application of domestic wastewater as compared to fresh water $(5145 \mathrm{~kg} / \mathrm{ha})$. However it was on par with treated wastewater alternated with domestic wastewater (7703 kg/ha) (Table 3). Improvement in the growth and development of the plants irrigated with treated sewage water was due to increased supply of nitrogen in the form of $\mathrm{NH}_{4}{ }^{+}$which promoted dry matter production and increase in leaf nitrogen accumulation in soil (Norgueira et al., 2013). Al-Lahham (2003) observed increase in the fruit size and weight with increase in quantity of the treated wastewater clearly indicating the increase in nutrient addition leading to increase in the yield. Finley et al., (2008) obtained higher yields with untreated wastewater irrigation as compared to fresh water irrigation. Similar results were observed by Almuktar et al., (2015), Prazeres et al., (2014) and Cireli et al., (2012) with application of treated wastewater in comparison to fresh water application alone. 


\section{Water productivity and economic analysis}

The total water applied including effective rainfall for all the treatments was $541 \mathrm{~mm}$. Higher water productivity of $164.03 \mathrm{~kg} / \mathrm{ha}-\mathrm{cm}$ was achieved with domestic wastewater followed by treated wastewater altered with domestic wastewater $(142.38 \mathrm{~kg} / \mathrm{ha}-\mathrm{cm})$ and lower water productivity of $95.103 \mathrm{~kg} / \mathrm{ha}-\mathrm{cm}$ was recorded with fresh water (Table 4).

Higher net return (Rs 1,34,440/ha) and B:C ratio (4.12) were observed with application of domestic wastewater as compared to all other treatments except treated waste water altered with domestic waste water (Rs.1,11,023/ha and 3.58 , respectively). The highest and lowest net profit of Rs 2485 and 1106 were obtained per $\mathrm{cm}$ use of water in case of domestic wastewater and fresh water irrigated cluster bean. However the combination of TWW with DWW also recorded higher net profit of Rs 2052 per $\mathrm{cm}$ water used. Treated sewage wastewater usage was economical in comparison to the irrigation through fresh bore well water (Nogueira et al., 2013). Similar results were also observed by Manjunatha et al., $\left(2017^{\mathrm{a}}\right.$ and $\left.2017^{\mathrm{b}}\right)$ and reported that irrigating brinjal and chilli crops with domestic wastewater resulted in significantly higher yield, water productivity, net returns and $\mathrm{B}: \mathrm{C}$ ratio followed by alternative application of engineered constructed wetland treated wastewater and domestic wastewater.

\section{Soil properties}

Insignificant difference with respect to soil reaction $(\mathrm{pH})$ and conductivity (EC) was recorded under different sources of irrigation at $0-20 \mathrm{~cm}$ and $20-40 \mathrm{~cm}$ soil depth Significant difference was recorded with respect to available nitrogen content observed at both depths due to different source of the irrigation water. Higher available nitrogen content $(263.42 \mathrm{~kg} / \mathrm{ha})$ was recorded in the plots irrigated with the domestic waste water at $0-20 \mathrm{~cm}$ depth, which was on par with treated waste water alternated with domestic waste water. Lower available nitrogen content $(206.95 \mathrm{~kg} / \mathrm{ha})$ was recorded in the soil irrigated with fresh water which was on par with freshwater altered with domestic wastewater (Table 5). Similar trend with respect to the available nitrogen content in the soil was observed at $20-40 \mathrm{~cm}$ depth.

Table.1 Initial soil properties of the experimental site

\begin{tabular}{|c|c|}
\hline Properties & Values \\
\hline pH & 7.10 \\
\hline $\operatorname{EC}\left(\mathrm{dS} \mathrm{m}^{-1}\right)$ & 0.42 \\
\hline Organic carbon $\left(\mathrm{g} \mathrm{kg}^{-1}\right)$ & 4.4 \\
\hline Available nitrogen $\left(\mathrm{kg} \mathrm{ha}^{-1}\right)$ & 173.2 \\
\hline Available Phosphorus $\left(\mathrm{kg} \mathrm{ha}^{-1}\right)$ & 27.3 \\
\hline Available Potassium $\left(\mathrm{kg} \mathrm{ha}^{-1}\right)$ & 423.5 \\
\hline Exch-Ca $\left[\mathrm{cmol}\left(\mathbf{p}^{+}\right) \mathrm{kg}^{-1}\right]$ & 18.5 \\
\hline Exch-Mg $\left[\mathrm{cmol}\left(\mathrm{p}^{+}\right) \mathrm{kg}^{-1}\right]$ & 12.25 \\
\hline Available zinc (mg/kg) & 1.4 \\
\hline Available iron (mg/kg) & 5.3 \\
\hline Bulk density $\left(\mathrm{Mg} \mathrm{m}^{-3}\right)$ & 1.42 \\
\hline Water soluble aggregates (\%) & 39.50 \\
\hline
\end{tabular}


Table.2 Chemical properties of the different source of irrigation water during the cropping period

\begin{tabular}{|c|c|c|c|}
\hline Parameters & $\begin{array}{c}\text { Fresh water } \\
\text { /bore well water }\end{array}$ & Domestic wastewater & ECWL treated water \\
\hline pH & 7.68 & 7.51 & 7.48 \\
\hline$E C\left(d S ~ m^{-1}\right)$ & 0.79 & 1.37 & 1.21 \\
\hline Total N (mg/l) & 0.65 & 20.8 & 11.5 \\
\hline $\mathrm{NH}_{4}^{+}-\mathrm{N}(\mathrm{mg} / \mathrm{l})$ & 0.35 & 12.0 & 5.8 \\
\hline $\mathrm{NO}_{3^{-}}^{-} \mathrm{N}(\mathrm{mg} / \mathrm{l})$ & 0.2 & 5.2 & 2.7 \\
\hline Phosphate (ppm) & 0.3 & 10.1 & 5.6 \\
\hline $\mathrm{Ca}+\mathrm{Mg}(\mathrm{me} / \mathrm{l})$ & 4.2 & 10.8 & 7.4 \\
\hline Sodium (ppm) & 3.2 & 8.1 & 5.6 \\
\hline Potassium (ppm) & 5.1 & 5.4 & 3.8 \\
\hline Chloride (ppm) & 2.1 & 7.2 & 4.8 \\
\hline Bicarbonate (me/l) & 2.5 & 10.3 & 4.9 \\
\hline
\end{tabular}

Table.3 Vegetative growth and yield parameters of cluster bean as influenced by different sources of irrigation water

\begin{tabular}{|c|c|c|c|c|c|}
\hline Source of irrigation water & $\begin{array}{c}\text { Plant } \\
\text { height } \\
(\mathrm{cm})\end{array}$ & $\begin{array}{c}\text { No. of } \\
\text { branches/ } \\
\text { plant }\end{array}$ & $\begin{array}{l}\text { No. of } \\
\text { fruits } \\
\text { /plant }\end{array}$ & $\begin{array}{l}\text { Fruit weight } \\
\text { /plant (g) }\end{array}$ & $\begin{array}{c}\text { Yield } \\
\text { (kg/ha) }\end{array}$ \\
\hline $\mathrm{T}_{1}$ : Domestic wastewater (DWW) & 75.15 & 7.48 & 70.79 & 141.57 & 8874 \\
\hline$T_{2}:$ Treated wastewater $(\mathrm{TWW})$ & 68.52 & 6.92 & 65.87 & 131.73 & 6229 \\
\hline$T_{3}:$ Freshwater $(F W)$ & 63.48 & 6.35 & 58.37 & 119.23 & 5145 \\
\hline$T_{4}:$ Freshwater + Domestic wastewater & 69.11 & 7.00 & 64.34 & 130.83 & 6682 \\
\hline$T_{5}:$ Freshwater + Treated wastewater & 64.60 & 6.50 & 65.41 & 128.68 & 6202 \\
\hline$T_{6}:$ Treated wastewater + Domestic wastewater & 71.92 & 7.38 & 67.07 & 134.15 & 7703 \\
\hline S.Em \pm & 2.85 & 0.47 & 2.17 & 4.34 & 436 \\
\hline $\mathrm{CD}(\mathrm{P}=\mathbf{0 . 0 5})$ & 8.58 & NS & 6.54 & 13.09 & 1243 \\
\hline
\end{tabular}

Table.4 Water productivity and net profit of cluster bean as influenced by different source of water

\begin{tabular}{|l|c|c|c|c|c|}
\hline \multicolumn{1}{|c|}{ Source of irrigation water } & $\begin{array}{c}\text { Water } \\
\text { productivity } \\
\text { (Kg/ha-cm) }\end{array}$ & $\begin{array}{c}\text { Gross return } \\
\text { (Rs/ha)\# }\end{array}$ & $\begin{array}{c}\text { Net return } \\
\text { (Rs/ha) }\end{array}$ & $\begin{array}{c}\text { Net profit / } \\
\text { cm of water } \\
\text { (Rs) }\end{array}$ & B:C ratio \\
\hline $\mathbf{T}_{\mathbf{1}}:$ Domestic wastewater $(\mathbf{D W W})$ & 164.03 & 177480 & 134440 & 2485 & 4.12 \\
\hline $\mathbf{T}_{\mathbf{2}}:$ Treated wastewater $(\mathbf{T W W})$ & 115.14 & 124580 & 81540 & 1507 & 2.89 \\
\hline $\mathbf{T}_{\mathbf{3}}:$ Freshwater $\mathbf{( F W )}$ & 95.10 & 102900 & 59849 & 1106 & 2.39 \\
\hline $\mathbf{T}_{\mathbf{4}}:$ Freshwater + Domestic wastewater & 123.51 & 133640 & 90592 & 1674 & 3.10 \\
\hline $\mathbf{T}_{\mathbf{5}}:$ Freshwater + Treated wastewater & 114.64 & 124040 & 80992 & 1497 & 2.88 \\
\hline $\mathbf{T}_{\mathbf{6}}:$ Treated wastewater + Domestic wastewater & 142.38 & 154060 & 111023 & 2052 & 3.58 \\
\hline
\end{tabular}

\# Market rate of cluster bean Rs. 20/kg 
Table.5 Influence of different sources of irrigation water on soil chemical properties

\begin{tabular}{|c|c|c|c|c|c|c|c|c|c|c|c|c|}
\hline \multirow[t]{2}{*}{ Source of irrigation water } & \multicolumn{2}{|c|}{ pH } & \multicolumn{2}{|c|}{$\mathrm{EC}(\mathrm{dS} / \mathrm{m})$} & \multicolumn{2}{|c|}{ Nitrogen (kg/ha) } & \multicolumn{2}{|c|}{$\begin{array}{c}\text { Potassium } \\
\text { (kg/ha) }\end{array}$} & \multicolumn{2}{|c|}{ Ca $($ meq/100g) } & \multicolumn{2}{|c|}{$\operatorname{Mg}(\mathrm{meq} / \mathbf{1 0 0 g})$} \\
\hline & $\begin{array}{c}0-20 \\
\mathrm{~cm}\end{array}$ & $\begin{array}{c}20-40 \\
\mathrm{~cm}\end{array}$ & $\begin{array}{c}0-20 \\
\mathrm{~cm}\end{array}$ & $\begin{array}{c}20-40 \\
\mathrm{~cm}\end{array}$ & $\begin{array}{c}20-40 \\
\mathrm{~cm}\end{array}$ & $\begin{array}{c}0-20 \\
\mathrm{~cm}\end{array}$ & $\begin{array}{c}20-40 \\
\mathrm{~cm}\end{array}$ & $\begin{array}{c}20-40 \\
\mathrm{~cm}\end{array}$ & $\begin{array}{c}0-20 \\
\mathrm{~cm}\end{array}$ & $\begin{array}{c}20-40 \\
\mathrm{~cm}\end{array}$ & $\begin{array}{c}0-20 \\
\mathrm{~cm}\end{array}$ & $\begin{array}{c}20-40 \\
\mathrm{~cm}\end{array}$ \\
\hline $\begin{array}{l}T_{1}: \text { Domestic wastewater } \\
(\mathrm{DWW})\end{array}$ & 7.87 & 7.87 & 0.452 & 0.340 & 263.42 & 222.66 & 443.63 & 293.10 & 26.50 & 22.50 & 13.75 & 12.75 \\
\hline $\begin{array}{l}T_{2}: \text { Treated wastewater } \\
(\mathrm{TWW})\end{array}$ & 7.87 & 7.88 & 0.550 & 0.382 & 238.34 & 197.57 & 423.80 & 258.10 & 22.00 & 20.00 & 14.75 & 13.75 \\
\hline$T_{3}:$ Freshwater $(F W)$ & 7.94 & 7.85 & 0.526 & 0.456 & 206.95 & 159.93 & 396.15 & 266.45 & 19.25 & 16.50 & 11.50 & 15.50 \\
\hline $\begin{array}{l}\mathrm{T}_{4}: \text { Freshwater }+ \\
\text { Domestic wastewater }\end{array}$ & 7.91 & 7.83 & 0.575 & 0.460 & 210.09 & 191.30 & 421.68 & 258.40 & 21.25 & 20.50 & 13.50 & 15.00 \\
\hline $\begin{array}{l}T_{5}: \text { Freshwater + Treated } \\
\text { wastewater }\end{array}$ & 7.88 & 7.86 & 0.559 & 0.418 & 238.34 & 203.84 & 414.65 & 252.15 & 19.80 & 22.00 & 21.70 & 10.25 \\
\hline $\begin{array}{l}T_{6}: \text { Treated wastewater }+ \\
\text { Domestic wastewater }\end{array}$ & 7.86 & 7.91 & 0.474 & 0.340 & 260.29 & 213.25 & 440.75 & 291.80 & 22.75 & 23.25 & 16.50 & 13.25 \\
\hline SEm \pm & 0.04 & 0.02 & 0.062 & 0.037 & 7.68 & 6.99 & 8.07 & 10.32 & 1.39 & 1.93 & 2.76 & 1.94 \\
\hline $\mathrm{CD}(\mathrm{p}=0.05)$ & NS & NS & NS & NS & 23.14 & 21.07 & 24.34 & 31.10 & 4.19 & NS & NS & NS \\
\hline
\end{tabular}


Conjunctive use of the domestic wastewater with treated wastewater resulted in progressive improvement comparable to the application of the domestic wastewater alone at both depths of soils. This is attributed to the addition of higher amount of nitrogen to soil through treated waste water and domestic waste water. Such results were also reported by Salakinkop and Hunshal (2014) and Abdel (2015).

Sources of irrigation water resulted in significant difference with respect to potassium content in the soil at different depths. Higher amount of potassium (443.63 $\mathrm{kg} / \mathrm{ha}$ ) was recorded in domestic sewage water irrigation which was on par with treated waste water alternated with domestic waste water at $0-20 \mathrm{~cm}$. Lower values of the potassium was recorded with the application of freshwater as source of irrigation. Similar trend of results was recorded at a lower soil depth of $20-40 \mathrm{~cm}$. These results are in conformity with the findings of Abdel (2015), Salakinkop and Hunshal (2014), and Chopra et al., (2013).

Significant difference in concentration of the calcium due to the source of irrigation water was recorded at $0-20 \mathrm{~cm}$ (Table 5). Higher calcium concentration was recorded with domestic wastewater application, which was on par with all the other sources of irrigation water except fresh water. Whereas, the difference in calcium concentration at 20-40 $\mathrm{cm}$ depth was insignificant. Magnesium concentration observed at $0-20 \mathrm{~cm}$ and $20-40$ $\mathrm{cm}$ depth resulted in non-significant difference due to the source of irrigation water.

Engineered constructed wetland treated wastewater can be used as irrigation source for recovery of water and nutrients resource in areas of fresh water shortage with exercised care in selection of crops and avoiding direct contact of the vegetables with treated wastewater. Instead of direct usage of domestic sewage water alone for vegetable production, conjunctive use of domestic sewage water either with Engineered constructed wet land treated domestic sewage water or with fresh water seems to be an better alternate/viable solution from the point of yield, economics, net profit and environment aspects.

\section{Acknowledgment}

Authors acknowledge the resources availed through a mirror project between EU and Department of Bio-Technology, Govt. of India - Water4crop "Integrating bio-treated wastewater reuse with enhanced water use efficiency to support the green economy in Europe and India".

\section{References}

Abdel, A., 2015, Impact of treated wastewater irrigation on soil chemical properties and crop productivity. Int. J. Water Res. Arid Environ., 4 (1): 30-36.

Al-Lahham, O., El Assi, N. M. and Fayyud, M., 2003, Impact of treated wastewater irrigation on quality attributes and contamination of tomato fruit. Agric. Water Mgmnt., 61: 51-62.

Almuktar, S.A.A.A.N., Scholz, M., Al-Isawi, R. H. K. and Sani, A., 2015, Recycling of domestic wastewater treated by vertical flow wetlands for irrigating chilli and sweet peppers. Agric. Water Mgmnt., 149: 1-22.

Azize Dogan demir and Ustan Sahin, 2017, Effects of different irrigation practices using treated wastewater on tomato yields, quality, water productivity, and soil and fruit mineral contents, Environmental Science Pollution Research, 24: 24856-24879

Chen, Y., Wen, Y., Zhou, Q., Vymazal, J., 
2014, Effects of plant biomass on denitrifying genes in subsurface-flow constructed wetlands. Bioresour. Technol. 157: 341-345.

Chopra, A. K., Pathak, C. and Pathak, S., 2013, Impact of domestic wastewater irrigation on soil properties and crop yield. New York Sci. J., 3(10): 52-58.

Cireli, G.L., Consoli, S., Licciardello, F., Aiello, R., Giuffrida, F., Leonardi, C., 2012, Treated municipal wastewater reuse in vegetable production. Agric. Water Mngmt., 104: 163-170.

Datta, A., Wani S.P., Patil, M.D. and Tilak. A.S., 2016, Field scale evaluation of seasonal wastewater treatment efficiencies of free surface-constructed wetlands in ICRISAT, India, Current Science, 110 (9): 1756-1763.

Finely, S., Barrington, S., and Lyew, D., 2008, Reuse of domestic grey water for the irrigation of food crops. Water Air Soil Pollution, 199: 235-245.

Gomez, K. A. and Gomez, A. A., 1984, Statistical procedure for agricultural research, John Willey and Sons, New York. India.

Haruvy, N., 1997, Agricultural reuse of wastewater: Nation-wide cost-benefit analysis. Agri. Ecosystems. Environ., 66: 113-119.

Jan Vymazal, 2014, Constructed wetlands for treatment of industrial wastewaters: A review, Ecological Engineering, 73:724-751

Kaur, R., Wani, S. P., Singh, A. K. and Lal, K., 2012, Wastewater production, treatment and use in India, Country Report India.

Kivaisi, A.K., 2001, The potential for constructed wetlands for wastewater treatment and reuse in developing countries: a review. Ecological Engineering, 16 (4), 545-560.

Lopez, A. Pollice, G. Laera, A. Lonigro, P. Rubino, 2010, Membrane filtration of municipal wastewater effluents for implementing agricultural reuse in Southern Italy. Water Sci. Technol., 62 (5): 1121-1128.

Manjuntha, M. V., Manjunatha Hebbara, Prasannakumara, B. H., Sunil Satyareddi and Dasog, G.S., 2017, Effect of untreated and engineered constructed wetland treated wastewater on yield, water productivity and economics of brinjal. Green Farming, 8(3): 676-679.

Manjuntha, M. V., Prasanna kumara, B. H., Sunil Satyareddi and Manjunatha Hebbara, 2017, Yield, water productivity and economics of green chilli as influenced by engineered constructed wetland treated and untreated domestic sewage water Int. Journal of Current Microbiology and Applied Sciences 6 (4): 2125-2132.

Meli, S., Porto, M., Belligno, A., Bufo, S.A., Mazzatura, A., Scopa, A., 2002, Influence of irrigation with lagooned urban wastewater on chimica and microbiological soil parameters in a citrus orchard under Mediterranean condition. Sci. Total Environ. 285: 6977.

Norgueira, S. F., Prereia, B. F.F., Gomes, T. M. Paula, A M., Santos, J. A. and Montes, C. R., 2013, Treated sewage effluent: Agronomical and economical aspects on Bermuda grass production. Agric. Water Mngmt., 116: 151-159.

Prazeres, A., Carvalho, F., Rivas, J., Patanita, M. and Dores, J., 2014, Reuse of pretreated cheese whey wastewater for industrial tomato (Lycopersicum esculentum Mill.) production. Agric. Water Mngmt., 140: 87-95.

Rai, U.N., Tripathi, R.D., Singh, N.K., Upadhyay, A.K., Dwivedi, S., Shukla, M.K., Mallick, S., Singh, S.N., Nautiyal, C.S., 2013, Constructed wetland as an ecotechnological tool for 
pollution treatment for conservation of Ganga river. Bioresour. Technol. 148: 535-541.

Rousseau, D.P.L., Vanrolleghem, P.A., De Pauw, N., 2004. Constructed wetlands in Flanders: a performance analysis. Ecological Engineering, 23: 151-163.

Salakinkop, S. R. and Hunshal, C. S., 2014, Domestic sewage irrigation on dynamics of nutrients and heavy metals in soil and wheat (Triticum aestivum L.) production. Int. J. Org. Waste Agric., 3: 64-75.

Suhad A.A.A.N. Almuktar, Suhail N. Abed, Miklas Scholz, 2017, Recycling of domestic wastewater treated by verticalflow wetlands for irrigation of two consecutive Capsicum annuum generations, Ecological Engineering, 107: 82-98

Tandon, H. L. S., 1998, Methods of analysis of soils, plants, water and fertilizers. Fertilizer development and consultation organization. New Delhi, pp. 9-16.

Thapliyal, A., Vasudevan, P., Dastidar, M. G., Tandon, M. and Mishra, S., 2011, Irrigation with domestic wastewater: Response on growth and yield of ladies finger (Abelmoschus esculentus) on soil nutrients. J. Environ. Biol., 32: 645-65.

\section{How to cite this article:}

Manjunatha, M.V., Sunil A. Satyareddi, B.H. Prasanna Kumar and Manjunatha Hebbara. 2019. Response of Treated and Untreated Domestic Waste Water Irrigation on Yield, Water Productivity and Economics of Cluster Bean. Int.J.Curr.Microbiol.App.Sci. 8(07): 2483-2491. doi: https://doi.org/10.20546/ijcmas.2019.807.306 